\title{
Inhibition of haem-iron absorption in man by calcium
}

\author{
BY LEIFHALLBERG, LENA ROSSANDER-HULTHEN, MATS BRUNE \\ AND ANN GLEERUP \\ Departments of Internal Medicine II and Clinical Nutrition, University of Göteborg, Sahlgren \\ Hospital, S-413 45 Göteborg, Sweden
}

(Received 30 September 1991-Accepted 25 March 1992)

\begin{abstract}
The inhibiting effect of $\mathrm{Ca}$ on non-haem-Fe absorption is well established. Present studies showed that $\mathrm{Ca}$ inhibited haem-Fe absorption to the same extent when the same amount of $\mathrm{Ca}\left(165 \mathrm{mg} \mathrm{Ca}\right.$ as $\left.\mathrm{CaCl}_{2}\right)$ was added to a meal. Attempts were made to examine the mechanism for this inhibition in the present studies. Meat is the only known dietary factor influencing haem-Fe absorption. The present studies were designed to examine whether $\mathrm{Ca}$ interfered with the enhancing effect of meat on haem-Fe absorption. We found that the inhibition was the same whether biosynthetically radio-Fe-labelled haemoglobin was given in meals with or without meat. The haem-Fe absorption ratio with: without added Ca was 0.59 (SE 0.07) when $\mathrm{Ca}$ was added to a hamburger meal, and 0.52 (SE 0.03 ) when added to a wheat roll. These values were not significantly different $(t 0.95 ; P=0.35)$. The inhibition of haem-Fe absorption by $\mathrm{Ca}$ is, thus, a direct effect on the absorption of haem-Fe and not an indirect counteracting effect of the well-known enhancing effect of meat on haem-Fe absorption. Control studies were conducted to ensure that haemFe had not been degraded to non-haem-Fe during preparation of the foods. Since Ca inhibits the absorption of haem- and non-haem-Fe to the same extent, the present results strongly suggest that $\mathrm{Ca}$ interferes with the transport of Fe through the mucosal cell, and at a late stage, is common for haemand non-haem-Fe transport. The observations that Ca strongly interferes with the absorption of both haem- and non-haem-Fe have important nutritional implications.
\end{abstract}

Iron absorption: Calcium: Man: Haem-iron: Non-haem-iron

Recently we made the unexpected observation that $\mathrm{Ca}$, given as $\mathrm{CaCl}_{2}$, milk or cheese, inhibited the absorption of non-haem-Fe in a dose-related manner (Hallberg et al. 1991). In one of these studies we also unexpectedly observed that haem-Fe absorption from hamburgers was also significantly reduced when given together with $\mathrm{CaCl}_{2}$. Since the mechanisms for uptake into the mucosal cells are different for haem- and non-haem-Fe, these results suggested that the inhibition of the absorption of $\mathrm{Fe}$ by $\mathrm{Ca}$ was not located in the gastrointestinal lumen but rather in some unknown way related to the transport of Fe through the mucosal cells.

It is well known that meat can enhance the absorption of non-haem-Fe (Layrisse et al. 1968). It is also well known that considerably more haem-Fe is absorbed from a meal if given together with meat than if given without (Martinez-Torres \& Layrisse, 1971; Hallberg et al. 1979; Hallberg, 1981). The mechanism behind this enhancing effect of meat on both haem- and non-haem-Fe absorption is still not established. The observation in the previous study (Hallberg et al. 1991) that less haem-Fe was absorbed from a hamburger meal when given with $\mathrm{Ca}$ may, thus, have two possible explanations. One, that $\mathrm{Ca}$ interferes with the enhancing effect of meat on haem-Fe absorption, the other that $\mathrm{Ca}$ directly influences the absorption of haem-Fe. These alternatives were considered important to clarify and were, therefore, examined in the present paper by measuring the effect of $\mathrm{Ca}$ on 
haem-Fe absorption when biosynthetically radio-Fe-labelled haemoglobin was given with and without $\mathrm{Ca}$, either in a meal containing meat (hamburger) or a non-meat meal (wheat rolls).

\section{SUBJECTS AND METHODS}

\section{Subjects}

Twenty-eight subjects, twelve men and sixteen women, participated in the experiments. All subjects were healthy volunteers aged 24-65 years. Each group included both men and women. Some of the subjects in each group were regular blood donors, which provided a reasonable range of intersubject variation in Fe absorption. Subjects were given written information about the aims and procedures of the study. The project was approved by the ethical committee of the Medical Faculty of the University of Göteborg, Sweden.

\section{Experimental design}

Two studies were made to establish whether $\mathrm{Ca}$ had a direct inhibiting effect on haem-Fe absorption or if the effect was indirect by counteracting the enhancing effect of meat on haem-Fe absorption. In study 1 biosynthetically ${ }^{55} \mathrm{Fe}$ - or ${ }^{59} \mathrm{Fe}-$ labelled rabbit haemoglobin was mixed into minced meat, and in study 2 the labelled haemoglobin was mixed into the dough of wheat rolls. In each study the same subjects were given meals with and without added $\mathrm{Ca}$ when labelling the meals with two different radio-Fe isotopes.

In both studies each meal was served with two wheat rolls, each prepared from $40 \mathrm{~g}$ lowextraction $(55 \%)$ wheat flour to get rolls with a very low content of phytate. The dough also contained yeast, sugar, table salt and water. The non-haem-Fe content of two rolls (one serving) was adjusted to $3.8 \mathrm{mg}$ by adding ferrous sulphate to the dough. The native $\mathrm{Fe}$ content of the two rolls was $0.3 \mathrm{mg} / 80 \mathrm{~g}$ flour.

In study 1 two hamburgers were served together with the two wheat rolls and $150 \mathrm{ml}$ water. The two hamburgers in each meal contained together $(\mathrm{g})$ minced meat 85 , onion 5 , boiled potatoes 8 , egg 5 , salt and pepper. Radio-Fe-labelled rabbit haemoglobin $\left({ }^{55} \mathrm{Fe}\right.$ or ${ }^{59} \mathrm{Fe}$ ) was mixed into the meat batter before cooking. Each serving contained $1 \mathrm{mg}$ added haem-Fe and $0.5 \mathrm{mg}$ native haem-Fe. The cooking was done at low temperature to avoid a conversion of haem-Fe into non-haem-Fe (Schricker \& Miller, 1983; Martinez-Torres et al. 1987). As shown below, special studies were done to ensure that the present cooking procedure did not degrade the haem-Fe to non-haem-Fe.

In study 2 , the ${ }^{55} \mathrm{Fe}$ - or ${ }^{59} \mathrm{Fe}$-labelled rabbit haemoglobin was added to the water when making the dough. The two wheat rolls contained together $3 \mathrm{mg}$ haem-Fe. They were served with butter and $150 \mathrm{ml}$ water.

The haemoglobin-labelled hamburgers served with two plain rolls (study 1) or the haemoglobin-labelled wheat rolls (study 2) were given to each subject with or without $165 \mathrm{mg} \mathrm{Ca}$ as $\mathrm{CaCl}_{2}$ (a and $\mathbf{b}$ respectively) on alternate mornings after an overnight fast on four consecutive days in the order $\mathbf{a b b a}$ or baab. The $\mathbf{a}$ and $\mathbf{b}$ rolls were labelled with the two different radio-Fe isotopes, ${ }^{35} \mathrm{Fe}$ and ${ }^{59} \mathrm{Fe}$. A blood sample was drawn 2 weeks after serving the last meal to determine the content of ${ }^{55} \mathrm{Fe}$ and ${ }^{59} \mathrm{Fe}$. The total retention of ${ }^{59} \mathrm{Fe}$ was measured by whole-body counting at the same time, and the total retention of ${ }^{55} \mathrm{Fe}$ was calculated from the ${ }^{55} \mathrm{Fe}:{ }^{59} \mathrm{Fe}$ value in erythrocytes. An oral reference dose (see p. 535) was then given to the fasting subject as well as a second dose on the following morning. The absorption of the reference dose was then measured by whole-body counting 2 weeks later (for the method of expression of results, see p. 535).

To examine if haem-Fe had been converted into non-haem-Fe by the baking and cooking procedures, two kinds of control experiments were made. The usual method to measure 
whether the haem-Fe content in a meal had decreased during cooking is to determine the difference between the contents of total $\mathrm{Fe}$ and non-haem-Fe in the foods, before and after cooking (Schricker \& Miller, 1983; Martinez-Torres et al. 1987).

Considering the importance of the present findings of an inhibition of the absorption of haem-Fe by $\mathrm{Ca}$, we also conducted an experiment (study 3) where exactly the same hamburger meal as in study 1 was served to ten healthy volunteers. The haem-Fe in the meal was labelled as before with the ${ }^{55} \mathrm{Fe}-$ labelled rabbit haemoglobin. The non-haem-Fe in the same meal was also labelled with a trace amount of inorganic Fe using ${ }^{59} \mathrm{Fe}$-labelled $\mathrm{FeCl}_{3}$ in $0 \cdot 1 \mathrm{M}-\mathrm{HCl}$. Two servings were made of these doubly labelled hamburgers. After 2 weeks the $\mathrm{Fe}$ absorption of a ${ }^{59} \mathrm{Fe}$-labelled reference dose was measured (see below).

Labelled haemoglobin was prepared by intravenous administration of radio- $\mathrm{Fe}$ into rabbits. Details of the procedure were previously described (Hallberg, 1980). In study 1 and study 2 each meal contained $37 \mathrm{kBq}{ }^{55} \mathrm{Fe}$ or ${ }^{59} \mathrm{Fe}$. In study 3 , where only two meals were served, each meal contained $75 \mathrm{kBq}{ }^{55} \mathrm{Fe}$ and $75 \mathrm{kBq}{ }^{59} \mathrm{Fe}$.

\section{Oral reference doses}

A solution of $10 \mathrm{ml} 0.01 \mathrm{M}-\mathrm{HCl}$ containing $3 \mathrm{mg} \mathrm{Fe}$ as $\mathrm{FeSO}_{4}$ and $30 \mathrm{mg}$ ascorbic acid labelled with ${ }^{59} \mathrm{Fe}$ was used as a reference in all studies. The $10 \mathrm{ml}$ vials containing the $\mathrm{Fe}$ solution were rinsed twice with water, and this was also consumed. Each subject received two reference doses on two consecutive mornings after an overnight fast. No food or drink was allowed for $3 \mathrm{~h}$ after the reference dose. Each subject received a total of $36 \mathrm{kBq}{ }^{59} \mathrm{Fe}$.

\section{Expression of results of Fe absorption measurements}

The mean of the individual absorption ratios, Fe absorption from meals with or without added $\mathrm{CaCl}_{2}$, is an expression of the difference in bioavailability of haem between the two meals and an expression of the effect of the added $\mathrm{Ca}$. These mean ratios are considered to be the most accurate basis for comparisons between different experiments (Magnusson et al. 1981).

The absorption of haem-Fe is much less influenced by the Fe status than non-haem-Fe absorption. This is the reason why absorption values in the present paper have not been adjusted to a $40 \%$ reference dose absorption as we usually do with non-haem-Fe absorption values.

\section{Chemical measurements}

Samples of rolls and hamburgers were freeze-dried and ground to a powder in a porcelain mortar. Weighed amounts of this powder were analysed for total Fe (Björn-Rasmussen et al. 1976), Ca (Clegg et al. 1981) and phytic acid-P, using the Association of Official Analytical Chemists' method (Harland \& Oberleas, 1986). In rolls with a low content of phytate, $6 \mathrm{ml}$ of the original $\mathrm{HCl}$ extract was used instead of $1 \mathrm{ml}$ (original method) and the amount of $\mathrm{NaOH}-\mathrm{EDTA}$ was increased proportionally. This modification markedly increased the lower limit of detection of phytate in the extract. Non-haem-Fe was determined according to Hallgren (1953).

\section{Fe absorption measurements}

Relative absorption of ${ }^{55} \mathrm{Fe}$ and ${ }^{59} \mathrm{Fe}$ was calculated from analyses of blood samples. Absolute absorption of the two tracers was calculated from whole-body counting of ${ }^{59} \mathrm{Fe}$ and the relative absorption of the two tracers. Analyses of ${ }^{55} \mathrm{Fe}$ and ${ }^{59} \mathrm{Fe}$ in blood were made by a modification of the method described by Eakins \& Brown (1966), using a liquidscintillation spectrometer (Tri-Carb, Packard Instruments, Texas, USA). All procedures and methods of calculation have been described previously (Björn-Rasmussen et al. 1974; Hallberg, 1980). 
Table 1. Effect of calcium as calcium chloride (165 $\mathrm{mg} \mathrm{Ca}$ ) on haem-Fe absorption from a meat-containing meal (hamburger) in human subjects*

\begin{tabular}{|c|c|c|c|c|}
\hline \multirow[b]{2}{*}{ Subject } & \multicolumn{2}{|c|}{$\begin{array}{c}\text { Haem-Fe } \\
\text { absorption }(\%)\end{array}$} & \multirow[b]{2}{*}{$\begin{array}{l}\text { Fe absorption (\%) } \\
\text { (reference dose) }\end{array}$} & \multirow{2}{*}{$\begin{array}{c}\text { Absorption ratio } \\
\text { (with: without } \\
\text { added } \mathrm{Ca} \text { ) }\end{array}$} \\
\hline & $\begin{array}{l}\text { Without } \\
\text { added } \mathrm{Ca}\end{array}$ & $\begin{array}{c}\text { With } \\
\text { added } \mathrm{Ca}\end{array}$ & & \\
\hline $\mathrm{M} \dagger$ & $21 \cdot 2$ & $12 \cdot 9$ & 36.0 & 0.61 \\
\hline $\mathrm{F}$ & $40 \cdot 4$ & $9 \cdot 7$ & $82 \cdot 1$ & $0 \cdot 24$ \\
\hline $\mathrm{F}$ & $15 \cdot 4$ & $9 \cdot 8$ & $36 \cdot 6$ & 0.63 \\
\hline $\mathrm{F} \dagger$ & $38 \cdot 7$ & $20 \cdot 4$ & 86.0 & 0.53 \\
\hline $\mathrm{M}$ & $17 \cdot 4$ & $15 \cdot 6$ & $27 \cdot 3$ & 0.89 \\
\hline $\mathrm{M} \dagger$ & $16 \cdot 8$ & $12 \cdot 3$ & $45 \cdot 2$ & 0.73 \\
\hline $\mathrm{F}$ & 9.8 & $6 \cdot 5$ & $34 \cdot 8$ & 0.66 \\
\hline M & 21.8 & $9 \cdot 3$ & $12 \cdot 9$ & 0.43 \\
\hline Mean & $22 \cdot 7$ & $12 \cdot 1$ & $45 \cdot 1$ & 0.59 \\
\hline SEM & $3 \cdot 9$ & $1 \cdot 5$ & $9 \cdot 1$ & 0.07 \\
\hline
\end{tabular}

M, male; $F$, female.

* For details of procedures, see pp. $534-535$.

$\dagger$ Regular blood donor.

\section{Statistical methods}

All statistical analyses were made using a Statview II computer program (Abacus Concepts, Inc., Berkeley, CA, USA). For statistical comparisons the means with their standard errors of the individual absorption ratios in each experiment were used. The possible statistical significance of the difference between the mean absorption and 1 was examined by an unpaired, two-sided $t$ test.

\section{RESULTS}

The addition of $165 \mathrm{mg} \mathrm{Ca}$ as $\mathrm{CaCl}_{2}$ to the hamburgers in study 1 containing biosynthetically ${ }^{55} \mathrm{Fe}$ - or ${ }^{59} \mathrm{Fe}$-labelled haemoglobin reduced the haem-Fe absorption by $41 \%$. The absorption ratio with:without $\mathrm{Ca}$ was 0.59 (SE 0.07) which was highly significantly different from 1 ( $t 5 \cdot 86 ; P<0.001$; Table 1$)$.

In study 2 , where $165 \mathrm{mg}$ Ca was added to wheat rolls containing biosynthetically ${ }^{55} \mathrm{Fe}-$ or ${ }^{59} \mathrm{Fe}-$ labelled haemoglobin, haem-Fe absorption was reduced by $48 \%$. The absorption ratio with: without $\mathrm{Ca}$ was 0.52 (SE 0.03 ), which was highly significantly different from 1 ( $t$ 13.1; $P<0 \cdot 001$; Table 2).

The inhibition of haem-Fe absorption by $\mathrm{Ca}$ in studies 1 and 2 was not statistically different. The $t$ value in an unpaired two-sided test was $0.945(P=0.35)$.

In study 3 , the absorption values of haem-Fe and non-haem-Fe from hamburgers identical to those served in study 1 were compared. The mean absorption of haem-Fe was 22.1 (SE 1.77$) \%$ and of non-haem-Fe 9.8 (SE 2.03) \% ( $n$ 10). The mean value for the individual absorption ratios (haem-Fe:non-haem-Fe) was 3.71 (SE 1.01). This was significantly different from $1, t 2 \cdot 7 ; P=0.0122$. Since these ratios were skewly distributed the same analysis was also made after log transformation. The logarithms of the ratios were also significantly different from $0(t 4 \cdot 17 ; P=0 \cdot 0012)$. The mean reference dose absorption in study 3 was 40.0 (SE 6.87 ) \%. The reason for the skewness of the ratios is that the absorption of non-haem-Fe was strongly related to the absorption from the reference dose $\left(r^{2} 0.771\right)$, whereas the corresponding relationship between absorption of haem-Fe and absorption of reference doses was much lower and not significant $\left(r^{2} 0.042\right)$. 
Table 2. Effect of calcium as calcium chloride $(165 \mathrm{mg} \mathrm{Ca}$ ) on haem-Fe absorption from a non-meat meal (wheat rolls) in human subjects*

\begin{tabular}{|c|c|c|c|c|}
\hline \multirow[b]{2}{*}{ Subject } & \multicolumn{2}{|c|}{$\begin{array}{c}\text { Haem-Fe } \\
\text { absorption }(\%)\end{array}$} & \multirow[b]{2}{*}{$\begin{array}{l}\text { Fe absorption (\%) } \\
\text { (reference dose) }\end{array}$} & \multirow{2}{*}{$\begin{array}{l}\text { Absorption ratio } \\
\text { (with: without } \\
\text { added } \mathrm{Ca} \text { ) }\end{array}$} \\
\hline & $\begin{array}{l}\text { Without } \\
\text { added Ca }\end{array}$ & $\begin{array}{c}\text { With } \\
\text { added Ca }\end{array}$ & & \\
\hline $\mathrm{M} \dagger$ & $29 \cdot 4$ & $19 \cdot 7$ & $58 \cdot 7$ & 0.67 \\
\hline $\mathrm{M} \dagger$ & $24 \cdot 3$ & $15 \cdot 4$ & $22 \cdot 7$ & 0.63 \\
\hline $\mathrm{M} \dagger$ & $18 \cdot 0$ & $10 \cdot 9$ & $46 \cdot 7$ & 0.60 \\
\hline F & $9 \cdot 7$ & $3 \cdot 4$ & $39 \cdot 9$ & 0.35 \\
\hline $\mathbf{F} \dagger$ & $41 \cdot 6$ & $23 \cdot 9$ & $35 \cdot 6$ & 0.57 \\
\hline $\mathbf{F}$ & $17 \cdot 7$ & 9.5 & $22 \cdot 2$ & 0.54 \\
\hline $\mathrm{F}$ & $17 \cdot 3$ & 9.6 & $53 \cdot 5$ & 0.56 \\
\hline$F$ & $19 \cdot 2$ & $7 \cdot 7$ & 35.0 & 0.40 \\
\hline $\mathrm{M}$ & $11 \cdot 5$ & $4 \cdot 6$ & $12 \cdot 0$ & $0 \cdot 40$ \\
\hline M & $14 \cdot 6$ & $7 \cdot 1$ & $31 \cdot 2$ & 0.49 \\
\hline Mean & $20 \cdot 3$ & $11 \cdot 2$ & $35 \cdot 8$ & 0.52 \\
\hline SFM & $2 \cdot 3$ & 1.7 & 4.5 & 0.03 \\
\hline
\end{tabular}

The contents of total Fe and non-haem-Fe were determined in the dough and the bread, and in the hamburgers before and after cooking. The studies were done in triplicate. All foods, cooked and uncooked, were freeze-dried at the same time. There was no increase in the content of non-haem-Fe in the hamburgers after cooking that might have suggested a degradation of haem-Fe. In the bread containing haem-Fe there was a slight increase in the content of non-haem-Fe after baking $(26 \mathrm{mg} / \mathrm{kg}$ dry weight before baking and $28 \mathrm{mg} / \mathrm{kg}$ dry weight after baking). The total Fe content was $57 \mathrm{mg} / \mathrm{kg}$ dry weight and the calculated haem-Fe content thus decreased from 31 to $29 \mathrm{mg}$ or $6 \%$.

\section{DISCUSSION}

A main new finding in the present paper was that $\mathrm{Ca}$ inhibited haem-Fe absorption whether given with or without meat. This implies that the inhibition by $\mathrm{Ca}$ is a direct effect on the absorption of haem-Fe. The possibility that the inhibiting effect of $\mathrm{Ca}$ on haem-Fe absorption from hamburger meals might be due to a counteraction of the well-known enhancing effect of meat on haem-Fe absorption could, thus, be excluded.

The inhibiting effect of $\mathrm{Ca}$ on haem-Fe absorption was of the same magnitude as the inhibiting effect on the absorption of non-haem-Fe observed in a previous paper (Hallberg et al. 1991). The individual non-haem-Fe absorption ratios in the previous paper when wheat rolls were served with and without $165 \mathrm{mg} \mathrm{Ca}$ (mean value 0.54 (SE 0.07)) were not different from the individual haem-Fe absorption ratios in the present study (mean value 0.52 (SE 0.03)) when wheat rolls containing labelled haemoglobin were given with and without the same amount of Ca (Fig. 1). An unpaired, two-sided $t$ test showed that the difference between the two means was not statistically significant $(t 0.48, P=0.64)$.

The inhibiting effect of $\mathrm{Ca}$ on haem-Fe absorption reported in a previous paper (Hallberg et al. 1991) was slightly lower (mean absorption ratio 0.76 (SE 0.07)) than in the present studies. The difference, however, from present results $(0.59$ (SE 0.07)) was not 


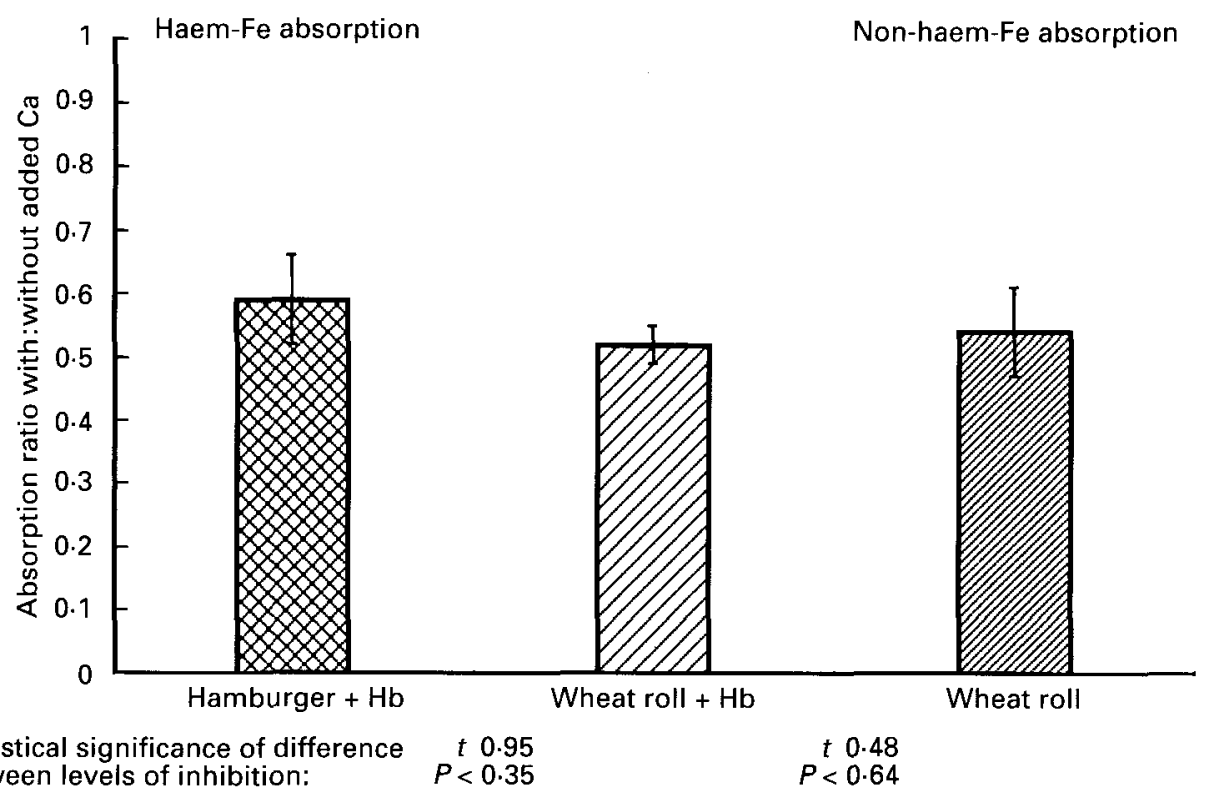

Fig. 1. Effect of calcium on inhibition of haem- and non-haem-Fe absorption in human subjects. Inhibition by $\mathrm{Ca}$ ( $165 \mathrm{mg}$ as calcium chloride) of haem-Fe absorption from a hamburger meal and a wheat roll (present study) was similar to that of haem-Fe absorption from wheat rolls and non-haem-Fe absorption in a previous study (Hallberg et al. 1991). For detail of procedures, see pp. 534-535.

statistically significant when applying an unpaired, two-tailed $t$ test $(t 1 \cdot 73 ; P=0 \cdot 10)$. A possible reason for the lower inhibition by $\mathrm{Ca}$ in the previous study $(0.76 v .0 .59)$ might be related to the fact that a frozen batch of biosynthetically ${ }^{55} \mathrm{Fe}$-labelled haemoglobin more than 2 years old was used in the previous study to label the haem-Fe in the hamburger given without $\mathrm{Ca}$ (Hallberg et al. 1991). This presumption is supported by the observed low mean absorption of haem-Fe of $14.6 \%$ from these hamburger meals given without $\mathrm{Ca}$ in that study. This value is lower than is usually observed from haem-Fe given together with meat (Hallberg et al. 1979) and should be compared with the present absorption of $22.7 \%$. In this perspective it is, thus, possible that the haemoglobin used in the previous study might have been partly denatured during the long storage, and that the inhibitory effect of $\mathrm{Ca}$ on haem-Fe absorption might have been underestimated.

In the interpretation of the present results it is important to be able to exclude that any appreciable fraction of the haem-Fe had been converted into non-haem-Fe during the cooking, since that would invalidate our conclusion that $\mathrm{Ca}$ had an effect on the absorption of haem-Fe. The possibility of a degradation, however, was strongly contradicted by the observations that there was no increase in the non-haem-Fe content after cooking or baking in the hamburger or the bread. An even stronger support for the conclusion that haem-Fe was not even functionally degraded during cooking was obtained in study 3 , in which both haem- and non-haem-Fe absorption were measured from an identical hamburger as served in study 1 . The mean absorption of haem-Fe was about the same in study 3 as in study 1 , and about the same as that observed by us and others from similar meals, containing both cooked and uncooked haem-Fe. Moreover, the absorption of the haem-Fe tracer was not related to the absorption from the reference dose, which was in sharp contrast to the absorption of the non-haem-Fe tracer from the same meals. It has previously been shown that this difference in pattern of absorption of haem- and non- 
haem-Fe in relation to $\mathrm{Fe}$ status is typical for the two types of $\mathrm{Fe}$ (Hallberg et al. 1979; Bezwoda et al. 1983). There are, thus, different independent pieces of evidence strongly supporting the conclusion that haem-Fe had not been degraded to non-haem-Fe during cooking of the hamburgers and that only negligible amounts of the haem-Fe in bread might have been degraded. The observed effect of $\mathrm{Ca}$ in the present two studies (study 1 and study 2) must, thus, be considered as true inhibitory effects of $\mathrm{Ca}$ on haem-Fe absorption.

The mechanisms of absorption of haem- and non-haem-Fe are different. Haem-Fe is absorbed into the mucosal cells via a special receptor (Gräsbäck et al. 1979) and in the form of an Fe-porphyrin complex that is split within the mucosal cells (Weintraub et al. 1968; Raffin et al. 1974). The balance of evidence indicates, however, that the final transport stages of Fe from the mucosal cells to the plasma are common for haem- and non-haemFe (Hallberg \& Sölvell, 1967). The present results thus strongly support the conclusion that there is a competitive inhibition between $\mathrm{Ca}$ and $\mathrm{Fe}$ in some of these final stages of intracellular transport in the intestinal mucosal cells. Further studies are needed to clarify the nature of such a stage and to investigate the possibility that there may be similar interactions between $\mathrm{Ca}$ and other minerals.

The practical implication of the present results is that the inhibition of $\mathrm{Fe}$ absorption by $\mathrm{Ca}$ is valid for both haem- and non-haem-Fe in the diet. In the large groups of subjects with high Fe requirements (children, teenagers and women at child-bearing age) attempts should be made to keep the Ca content low in most of the main meals providing most of the haemand non-haem-Fe. This can be done, for example, by reducing the intake of dairy products with these meals and by covering most of the $\mathrm{Ca}$ requirements in breakfast meals and in the in-between meals. Both $\mathrm{Fe}$ and $\mathrm{Ca}$ are nutritionally essential. Present interactions between $\mathrm{Ca}$ and $\mathrm{Fe}$ must be considered in dietary recommendations, in the composition of single meals, and in the design of daily menus in order to satisfy the requirements for both nutrients in a feasible way.

The authors acknowledge the support of: Swedish Medical Research Council Project B8819X-04721-13B; Swedish Council for Forestry and Agriculture Research 864/86, $31: 2$ and 599-89L-135:2; Swedish Agency for Research Co-operation with Developing Countries 9.49/SAREC 85/46:2.

\section{REFERENCES}

Bezwoda. W. R., Bothwell, T. H., Charlton, R. W., Torrance, J. D., MacPhail, A. P., Derman, D. P. \& Mayet, F. (1983). The relative dietary importance of haem and non-haem iron. South Aficican Medical Journal 64, $552-556$.

Björn-Rasmussen, E., Hallberg, L. \& Isaksson, B. (1974). Food iron absorption in man. Application of the twopool extrinsic tag method to measure heme and non-heme iron absorption from the whole diet. Journal of Clinical Investigation 53, 247-255.

Björn-Rasmussen, E., Hallberg, L., Magnusson, B., Rossander, L., Svanberg, B. \& Arvidsson, B. (1976). Measurement of iron absorption from composite meals. American Journal of Clinical Nutrition 29, $772-778$.

Clegg, M. S., Keen, C. L., Lönnerdal, B. \& Hurley, L. S. (1981). Influence of ashing techniques on the analysis of trace elements in animal tissue. I. Wet ashing. Biological Trace Elements Research 31, $107-115$.

Eakins, J. D. \& Brown, D. A. (1966). An improved method for the simultaneous determination of iron-55 and iron-59 in blood by liquid scintillation counting. International Journal of Applied Radiation and Isotopes 17. $391-397$.

Gräsbäck, R.. Kouvonen, I., Lundberg, M. \& Tenhunen, R. (1979). An intestinal receptor for heme. Scandinavian Journal of Haematology 23, 5-9.

Hallberg, L. (1980). Food iron absorption. In Methods in Hematology, pp. 116- I33 [J. D. Cook, editor]. London: Churchill.

Hallberg, L. (1981). Bioavailability of dietary iron in man. Annuat Review of Nutrition 1, 123-147.

Hallberg, L., Björn-Rasmussen, E., Howard, L. \& Rossander, L. (1979). A discussion of possible mechanisms for the absorption-promoting effect of meat and for the regulation of iron absorption. Scandinavian Joumal of Gastroenterology 14, 769-779.

Hallberg. L., Brune, M., Erlandsson, M., Sandberg, A.-S. \& Rossander-Hulthén, L. (1991). Calcium: effect of 
different amounts on nonheme- and heme-iron absorption in man. American Journal of Clinical Nutrition $\mathbf{5 3}$, 112-119.

Hallberg, L. \& Sölvell, L. (1967). Absorption of hemoglobin iron in man. Acta Medica Scandinavica 181, 335-354.

Hallgren, B. (1953). Determination of non-haem iron in tissues. Acta Societatis Medicorum Upsaliensis 59, 8499.

Harland, B. F. \& Oberleas, D. (1986). Anion-exchange method for determination of phytate in foods: Collaborative study. Journal of the Association of Official Analytical Chemists 69, 667-670.

Layrisse, M., Martinez-Torres, C. \& Roche, M. (1968). The effect of interaction of various foods on iron absorption. American Journal of Clinical Nutrition 21, 1175-1183.

Magnusson, B., Björn-Rasmussen, E., Hallberg, L. \& Rossander, L. (1981). Iron absorption in relation to iron status. Model proposed to express results of food iron absorption measurements. Scandinavian Journal of Haematology 27, 201-208.

Martinez-Torres, C. \& Layrisse, M. (1971). Iron absorption from veal muscle. American Journal of Clinical Nutrition 24, 531-540.

Martinez-Torres, C., Leets, I., Taylor, P., Ramirez, J., del Valle Camacho, M. \& Layrisse, M. (1987). Heme, ferritin, and vegetable iron absorption in humans from meals denatured of heme iron during the cooking of beef. Journal of Nutrition 116, 1720-1725.

Raffin, S. B., Woo, C. H., Roost, K. T., Price, D. C. \& Schmid, R. (1974). Intestinal absorption of hemoglobin iron - heme cleavage by mucosal heme oxygenase. Journal of Clinical Investigation 54, 1344-1352.

Schricker, B. R. \& Miller, D. D. (1983). Effects of cooking and chemical treatment on heme and non-heme iron in meat. Journal of Food Science 48, 1340-1344.

Weintraub, L. R., Weinstein, M. R., Huser, H.-J. \& Rafal, S. (1968). Absorption of hemoglobin iron. The role of a heme-splitting substance in intestinal mucosa. Journal of Clinical Investigation 47, 531-539. 